\title{
Endotoxaemia and serum tumour necrosis factor as prognostic markers in severe acute pancreatitis
}

\author{
A R Exley, T Leese, M P Holliday, R A Swann, J Cohen
}

\begin{abstract}
Endotoxaemia and circulating tumour necrosis factor are important prognostic factors in severe sepsis and are implicated in the pathogenesis of septic shock. Because clinical and pathological features in acute pancreatitis are similar to septic shock this study sought to determine whether endotoxin and tumour necrosis factor were prognostic factors in $\mathbf{3 8}$ patients with prognostically severe acute pancreatitis. Endotoxaemia, present in 19/37 (51\%) patients on day 1 , was more common in nonsurvivors than survivors $(10 / 11,91 \% v 9 / 26$, $35 \%, p=0.003)$. Day 1 serum endotoxin concentrations were higher in patients with a severe outcome (median (interquartile range) 314 (173-563) $\mathrm{pg} / \mathrm{ml}$ v $0(0-185) \mathrm{pg} / \mathrm{ml}, \mathrm{p}<0.01)$ and in non-survivors $(266(173-586) \mathrm{pg} / \mathrm{ml} v$ 0 (0-165) $\mathrm{pg} / \mathrm{ml}, \mathrm{p}<0.01)$. Serum tumour necrosis factor was detectable in 47 of 109 samples (43\%) from 38 patients (median $35 \mathrm{pg}$ / $\mathrm{ml}$, range 5-943 $\mathrm{pg} / \mathrm{ml}$ ). Day 1 serum tumour necrosis factor correlated with a worse prognostic score and a severe outcome in all patients $(n=38, r=0.36, p=0.027 ; r=0.33$, $\mathbf{p}<0.05$ ) and with mortality in patients with gall stones $(n=23, r=0.50, p=0.02)$. Our data suggest that endotoxin and tumour necrosis factor could be prognostic factors in severe acute pancreatitis.
\end{abstract}

(Gut 1992; 33: 1126-1128)

Pancreatic necrosis and local sepsis have been strongly implicated in the pathogenesis of evolving pancreatitis, ${ }^{1-3}$ although the initiating events remain controversial. High risk groups can be selected using prognostic scores and patients with pancreatic necrosis identified using modern imaging techniques. ${ }^{+6}$ Current strategies for treatment include the use of early surgery or peritoneal lavage.$^{67} \mathrm{~A}$ novel approach follows the observation that many clinical features in acute pancreatitis are also characteristic of septic shock - namely, the systemic illness and the significant mortality from the adult respiratory distress syndrome and multi organ failure. ${ }^{18}$ Accordingly, it has been suggested that severe acute pancreatitis, like septic shock, might be a consequence of excessive activation of macrophages and neutrophil polymorphs with the release of secondary mediators. ${ }^{8}$ In severe sepsis important prognostic factors which are also implicated in the pathogenesis of septic shock include endotoxaemia and the leucocyte products tumour necrosis factor, and interleukin-1.9 We have sought to detect the presence of endotoxaemia and serum tumour necrosis factor in patients with severe acute pancreatitis and determine whether they are prognostic factors for patient outcome.

\section{Methods}

PATIENTS

The study cohort consisted of the first 38 consecutive patients with prognostically severe acute pancreatitis, as defined by three or more adverse criteria, ${ }^{+}$taken from a randomised controlled study of intravenous fresh frozen plasma versus colloid. ${ }^{10}$ In our cohort there were 24 women and 14 men with a median age of 72.5 years (range 44-91). The aetiology of pancreatitis was gall stones in 23 patients, idiopathic in nine, alcohol in three, hypothermia in one, hyperlipidaemia in one, and postoperative in one. Patient outcome was defined as severe if multi organ failure or complications of acute pancreatitis developed." There were no significant differences between the fresh frozen plasma and plasma protein fraction subgroups at entry nor in outcome ${ }^{10}$; in particular the beta error for this study was $<5 \%$ (PPF $v$ fresh frozen plasma where alpha $=5 \%$, beta $=$ $3 \cdot 7 \%$ for severe outcome, beta $=2 \cdot 1 \%$ for death ${ }^{12}$ ).

Blood samples were drawn at presentation (day 1), day 3, and day 7 , into sterile pyrogen free tubes, centrifuged promptly and serum stored at $-70^{\circ} \mathrm{C}$ before analysis. Serum endotoxin concentrations were measured by a quantitative kinetic Limulus amoebocyte lysate microassay with a sensitivity of $25 \mathrm{pg} / \mathrm{ml} .{ }^{13}$ Serum tumour necrosis factor was measured using a modified tumour necrosis factor specific enzyme linked immunoadsorbent assay (ELISA) with a sensitivity of $5 \mathrm{pg} / \mathrm{ml} .{ }^{14} \mathrm{~A} p$ value $<0.05$ was regarded as statistically significant using Spearman rank correlation, two-tailed Mann Whitney U tests and Fisher's exact test.

\section{Results}

Fourteen of 38 patients with prognostically severe acute pancreatitis had a severe outcome and there were 11 deaths (Table I, II). Blood cultures were negative in 11/17 patients and Gram negative bacteraemia was only found in patients 6 and 9. Patient 5 (mild outcome) had Viridans streptococci and coagulase negative stapylococci isolated as probable contaminants. Patient 25 (mild outcome) had Staphylococcus aureus isolated from blood cultures and a central venous line.

Endotoxaemia was present in 19/37 (51\%) patients at presentation and was significantly more common in non-survivors than survivors $(10 / 11,91 \% v 9 / 26,35 \%, \mathrm{p}=0.003$, Figure 1). Serum endotoxin at presentation was signific-
Correspondence to:

Dr A R Exley, Department of Immunology, Medical School B15 2TT.

Accepted for publication 11 November 1991 
antly higher in patients who had a severe outcome (median (interquartile range) 314 (173563) $\mathrm{pg} / \mathrm{ml} v 0(0-185) \mathrm{pg} / \mathrm{ml}$ ) and in nonsurvivors $(266(173-586) \mathrm{pg} / \mathrm{ml} v 0(0-165) \mathrm{pg} /$ $\mathrm{ml}, \mathrm{p}<0 \cdot 01$, Figure 2, Table II).

Serum tumour necrosis factor was detectable in 47 of 109 samples, $43 \%$, from 38 patients (median $35 \mathrm{pg} / \mathrm{ml}$, range $5-943 \mathrm{pg} / \mathrm{ml}$ ). At presentation 11 of 38 patients, $30 \%$, were tumour necrosis factor positive (median $44 \mathrm{pg}$ / $\mathrm{ml}$, range $8-260 \mathrm{pg} / \mathrm{ml}$, Figure 2, Table II). Serum tumour necrosis factor at presentation correlated with a worse prognostic score and a severe outcome in all patients $(r=0.36, p=0.027$, $\mathrm{r}=0.33, \mathrm{p}<0.05)$ and prognostic score, outcome and mortality in patients with gall stones $(r=$ $0.58, \mathrm{p}=0.005, \mathrm{r}=0.60, \mathrm{p}=0.005, \mathrm{r}=0.50$, $\mathrm{p}=0.02)$. Six of $26(23 \%)$ survivors were tumour necrosis factor positive at entry versus five of 11 (45\%) non-survivors (median tumour necrosis factor $19 \mathrm{pg} / \mathrm{ml}$, range $8-48 \mathrm{pg} / \mathrm{ml} v 86 \mathrm{pg} / \mathrm{ml}$, range $17-260 \mathrm{pg} / \mathrm{ml}, \mathrm{p}=0.08$ ).

\section{Discussion}

The detection of circulating endotoxin and tumour necrosis factor correlates with mortality from severe sepsis, their induction in susceptible animals reproduces septic shock and their

TABLE I Patients with severe outcome: presenting features

\begin{tabular}{|c|c|c|c|c|c|}
\hline No & $\begin{array}{l}\text { Age } \\
(y r)\end{array}$ & Sex & Aetiology & $\begin{array}{l}\text { Prognostic } \\
\text { score }\end{array}$ & Blood cultures \\
\hline 6 & 67 & M & Idiopathic & 5 & $\begin{array}{l}\text { Escherichia coli, } \\
\star{ }^{\star} \text { Coagulase-ve Staphylococci }\end{array}$ \\
\hline 7 & 73 & $M$ & Idiopathic & 3 & Negative \\
\hline 9 & 81 & $\mathbf{F}$ & Gall stones & 5 & Coliforms, Streptococcus faecalis \\
\hline 11 & 57 & M & Gall stones & 3 & N/A \\
\hline 14 & 81 & $M$ & Gall stones & 4 & Negative \\
\hline 19 & 76 & $M$ & Idiopathic & 3 & $\star$ Coagulase-ve Staphylococci \\
\hline 20 & 58 & $M$ & Gall stones & 4 & N/A \\
\hline 21 & 84 & $M$ & Idiopathic & 3 & N/A \\
\hline 22 & 78 & $\mathrm{~F}$ & Gall stones & 3 & N/A \\
\hline 26 & 61 & $\mathrm{~F}$ & Idiopathic & 3 & Negative \\
\hline 30 & 91 & $\mathrm{~F}$ & Hypothermia & 3 & $\mathrm{~N} / \mathrm{A}$ \\
\hline 35 & 77 & M & Alcohol & 3 & ${ }^{\star}$ Staphylococcus aureus \\
\hline 36 & 60 & $\mathrm{~F}$ & Gall stones & 3 & Negative \\
\hline 39 & 63 & $\mathrm{~F}$ & $\begin{array}{l}\text { Alcohol+gall } \\
\text { stones }\end{array}$ & 3 & $\mathrm{~N} / \mathrm{A}$ \\
\hline
\end{tabular}

No: patient's trial number; prognostic score: modified Glasgow prognostic score where $\geq 3$ adverse criteria indicates prognostically severe acute pancreatitis $\left(\mathrm{ref}^{+}\right)$. yr: years; $\mathrm{F}$ : female; $\mathrm{M}:$ male $\star$ probable skin contaminants; Coagulase-ve coagulase negative; N/A not available.

TABLE II Patients with severe outcome: Day 1 tumour necrosis factor, endotoxin and complications

\begin{tabular}{|c|c|c|c|c|}
\hline No & $\begin{array}{l}\text { Tumour } \\
\text { necrosis } \\
\text { factor }\end{array}$ & Endotoxin & Complications & Survival \\
\hline 6 & 0 & 188 & Multi organ failure & Died day 15 \\
\hline 7 & 51 & 314 & $\begin{array}{l}\text { Toxic } \\
\text { Pancreatic necrosis }+ \text { abscess }\end{array}$ & Died day 30 \\
\hline 9 & 18 & 218 & $\begin{array}{l}\text { Severe cholangitis, cardiac failure, ileus pancreatic } \\
\text { phlegmon }\end{array}$ & Home day 90 \\
\hline 11 & 17 & 160 & Multi organ failure & Died day 3 \\
\hline 14 & 260 & 595 & $\begin{array}{l}\text { Toxic } \\
\text { Pancreatic necrosis+abscess }\end{array}$ & Died day 30 \\
\hline 19 & 0 & 359 & Multi organ failure & Died day 8 \\
\hline 20 & 194 & 173 & $\begin{array}{l}\text { Toxic } \\
\text { Pancreatic necrosis + abscess }\end{array}$ & Died day 30 \\
\hline $\begin{array}{l}21 \\
22\end{array}$ & $\begin{array}{l}0 \\
0\end{array}$ & $\begin{array}{r}183 \\
0\end{array}$ & $\begin{array}{l}\text { Multi organ failure } \\
\text { Pancreatic pseudocyst }\end{array}$ & $\begin{array}{l}\text { Died day } 7 \\
\text { Home day } 11\end{array}$ \\
\hline 26 & 0 & 588 & $\begin{array}{l}\text { Ileus } \\
\text { Pancreatic phlegmon }\end{array}$ & Home day 19 \\
\hline $\begin{array}{l}30 \\
35\end{array}$ & $\begin{array}{r}86 \\
0\end{array}$ & $\begin{array}{l}530 \\
563\end{array}$ & $\begin{array}{l}\text { ARDS } \\
\text { Multi organ failure }\end{array}$ & $\begin{array}{l}\text { Died day } 3 \\
\text { Died day } 5\end{array}$ \\
\hline 36 & 0 & 0 & $\begin{array}{l}\text { Toxic } \\
\text { Pancreatic necrosis + abscess }\end{array}$ & Died day 34 \\
\hline 39 & 0 & 4315 & $\begin{array}{l}\text { ARDS } \\
\text { Pancreatic necrosis }\end{array}$ & Died day 36 \\
\hline
\end{tabular}

No: patient's trial number; TNF: serum tumour necrosis factor $\mathrm{pg} / \mathrm{ml}$; Endotoxin $\mathrm{pg} / \mathrm{ml}$; ARDS: adult respiratory distress syndrome. neutralisation by monoclonal antibodies significantly decreases mortality from severe sepsis implicating these factors in the pathogenesis of septic shock. ${ }^{915-17}$ Severe acute pancreatitis has clinical features common to septic shock prompting a search for common prognostic factors. Our data suggest endotoxaemia and serum tumour necrosis factor are prognostic factors for severity of outcome and mortality in severe acute pancreatitis.

In septic shock detection of endotoxaemia and serum tumour necrosis factor has not been universal, nor are tumour necrosis factor or endotoxin alone invariably lethal..$^{98-20}$ Our data on tumour necrosis factor and endotoxin in severe acute pancreatitis and previous small studies in acute pancreatitis are reminiscent of earlier work in septic shock. ${ }^{21-23}$ Current data from patients with severe sepsis suggest such discrepancies reflect the transient detection of mediators in blood, the importance of interacting mediators and the presence of endogenous

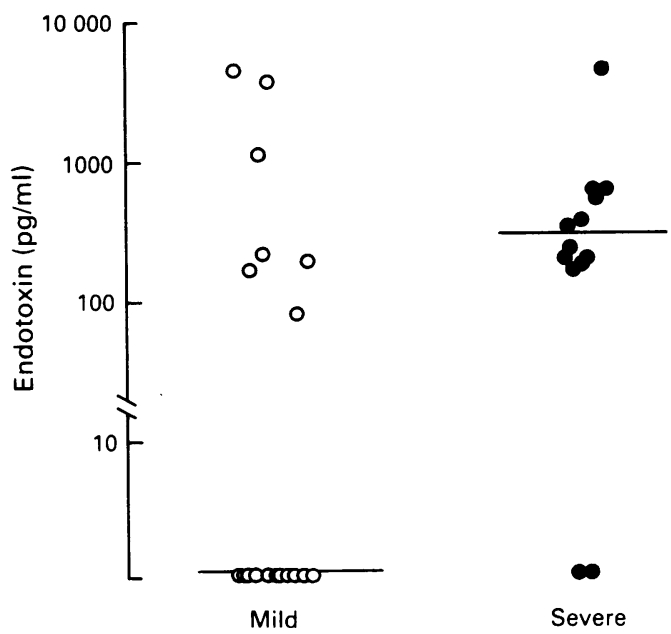

Fig $1 \mathrm{~A}$

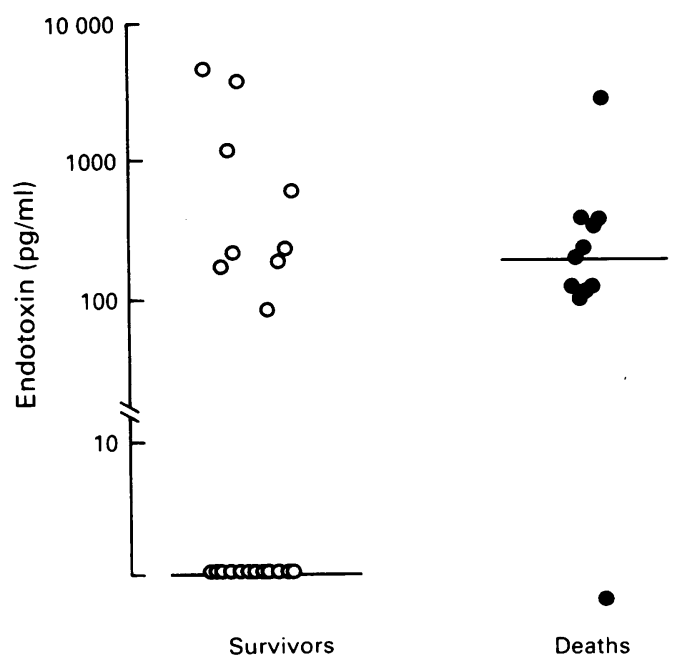

Fig $1 B$

Figure 1: A Serum endotoxin v outcome. Serum endotoxin in $\mathrm{pg} / \mathrm{ml}$, median values shown by horizontal bars. Serum endotoxin concentrations at entry were significantly higher in patients with a severe outcome v mild outcome, median $314 \mathrm{pg} /$ $\mathrm{ml}$ interquartile range $173-563 \mathrm{pg} / \mathrm{ml} \mathrm{v}$ median $0 \mathrm{pg} / \mathrm{ml}$ range $0-185 \mathrm{pg} / \mathrm{ml}, p<0 \cdot 01$. B Serum endotoxin $\mathrm{v}$ mortality. Serum endotoxin concentrations at entry were significantly higher in non-survivors than survivors, median $266 \mathrm{pg} / \mathrm{ml}$ interquartile range $173-586 \mathrm{pg} / \mathrm{ml} \mathrm{v}$ median $0 \mathrm{pg} /$ $\mathrm{ml}$ range $0-165 \mathrm{pg} / \mathrm{ml}, \mathrm{p}<0.01$. 
Figure 2: Serum tumour necrosis factor in $\mathrm{pg} / \mathrm{ml}$ $\square<10 \mathbb{Q}<20$ 进 $<100$ $\square<500$. A Serum tumour necrosis factor v outcome. Serum tumour necrosis factor correlated with a severe outcome - that is, multi organ failure or

complications of acute

pancreatitis, $r=0.33$

$p<0.05$ all patients, $r=0.60$ $p=0.005$ for patients with gall stones. Serum tumour necrosis factor concentration were significantly higher in patients with a severe outcome $p=0 \cdot 023$. B Serum tumour necrosis factor $\mathrm{v}$ mortality. In patients with gall stones serum tumour necrosis factor correlated with mortality and serum tumour necrosis factor concentrations were significantly higher in nonsurvivors than survivors, $n=$ $23, r=0.50, p=0.022$ and $n=23, p=0.022$

Gall stones

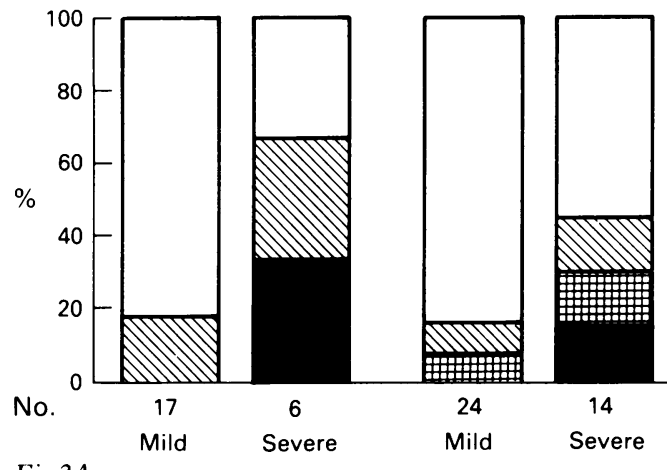

Fig 2A

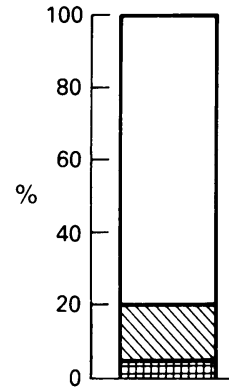

No.

19

Fig 2B

inhibitors. ${ }^{91924}$ Endotoxaemia without bacteraemia is a well recognised entity and in severe acute pancreatitis it might result from local sepsis, pancreatic and intraabdominal necrosis causing absorption of gut derived endotoxin. ${ }^{21} 2526$

The identification of endotoxin, phospholipase A2, tumour necrosis factor, and granulocyteelastase as prognostic factors in acute pancreatitis is insufficient to imply pathogenesis, despite persuasive analogies. ${ }^{8278}$ Intervention with specific antagonists to endotoxin, tumour necrosis factor and interleukin-1 should enable us to test the hypothesis that the progression of acute pancreatitis is driven by excessive leucocyte stimulation with the release of secondary mediators. ${ }^{816} 1724$

This work was supported in part by Celltech Limited, Slough (ARE); Leicestershire Health Authority and a Leicester Loca Research Grant (TL); and the Wellcome Trust (JC). These dat were presented in part in abstract form at the Pancreatic Society of Great Britain and Ireland, Manchester, November 1990

I Renner IG, Savage WT, Pantoja JL, Renner J. Death due to acute pancreatitis. A retrospective analysis of 405 autopsy cases. Dig Dis Sci 1985; 30: 1005-18.
2 Beger HG, Bittner R, Block S, Buchler M. Bacterial contamination of pancreatic necrosis. A prospective clinical study. Gastroenterology 1986; 91: 433-8.

3 Block S, Buchler M, Bittner R, Beger HG. Sepsis indicators in acute pancreatitis. Pancreas 1987; 2: 499-505.

4 Leese T, Shaw D. Comparison of three Glasgow multifactor prognostic scoring systems in acute pancreatitis. $\mathrm{Br} \mathcal{F}$ Surg $88 ; 75: 460-2$

5 Larvin M, McMahon MJ. APACHE-II score for assessmen and monitoring of acute pancreatitis. Lancet 1989; ii: 201-5.

6 Balthazar EJ, Robinson DL, Megibow AJ, Ranson JH. Acute pancreatitis: value of CT in establishing prognosis. Radiology 1990; 174: 331-6.

7 Ranson JH, Berman RS. Long peritoneal lavage decrease pancreatic sepsis in acute pancreatic. Ann Surg 1990; 211: 708-16.

8 Rinderknecht $\mathrm{H}$. Fatal pancreatitis, a consequence of excessive leukocyte stimulation? Int $\mathcal{f}$ Pancreatol 1988; 3: 105-12.

9 Wage A, Brandtzaeg P, Halstensen A, Kierulf P, Espevik T. The complex pattern of cytokines in serum from patien The complex pattern of cytokines in serum from patients interleukin 6, interleukin 1, and fatal outcome. F Exp Med 1989; 169: 333-8.

10 Leese T Holliday MP, Watkins M, Thomas WM Neoptolemos JP, Hall C, et al. A multi-centre controlled clinical trial of high volume fresh frozen plasma therapy in prognostically severe acute pancreatitis. Ann RCollSurgEng (in press)

11 Freeny PC. Classification of acute pancreatitis. Radiol Clin North Am 1989; 27: 1-3.

12 Colton T. Statistics in medicine. Boston: Little, Brown and Company, 1974: 120-3.

13 Cohen J, McConnell JS. Observations on the measurement and evaluation of endotoxemia by a quantitative Limulus lysate microassay. $\mathcal{F}$ Infect Dis 1984; 150: 916-24.

14 Exley AR, Cohen J. Optimal collection of blood samples for the measurement of tumour necrosis factor-alpha. Cytokine $1990 ; 2: 353-6$.

15 Tracey KJ, Vlassara H, Cerami A. Cachectin/tumour necrosis factor. Lancet 1989 ; i: 1122-6.

16 Silva AT, Appelmelk BJ, Buurman WA, Bayston KF, Cohe J. Monoclonal antibody to endotoxin core protects mice from E. coli sepsis by a mechanism independent of tumo necrosis factor and interleukin-6. F Infect Dis 1990; 162 : $454-9$.

17 Silva AT, Bayston KF, Cohen J. Prophylactic and therapeutic effects of a monoclonal antibody to tumor necrosis factor-a in experimental Gram-negative shock. F Infect Dis 1990 162: 421-7.

18 Debets JM, Kampmeijer R, Van der Linden MP, Buurman WA, Van der Linden CJ. Plasma tumor necrosis factor and mortality in critically ill septic patients. Crit Care Med 1989 mortality in

19 Cannon JG, Tompkins RG, Gelfand JA, Michie HR, Stanford $\mathrm{GG}$, van der Meer, et al. Circulating interleukin-l and tumo necrosis factor in septic shock and experimental endotoxin fever. F Infect Dis 1990; 161: 79-84.

20 Rothstein JL, Schreiber H. Synergy between tumor necrosis factor and bacterial products causes hemorrhagic necrosis and lethal shock in normal mice. Proc Natl Acad Sci USA 1988; 85: 607-11.

21 Foulis AK, Murray WR, Galloway D, McCartney AC, Lang E, Veitch J, et al. Endotoxaemia and complement activation in acute pancreatitis in man. Gut 1982; 23: 656-61.

22 Fugger $R$, Hamilton G, Rogy $M$, Herbst F, Kwasny W, Schemper $M$, et al. Prognostic significance of endotoxin determination in patients with severe intrababdominal infection. F Infect Dis 1990; 161: 1314-5.

23 Evans SW, Banks RE, Alexander D, McMahon MJ, Whicher JT. Is fatal pancreatitis the consequence of excessive macrophage stimulation? Gut 1990; 31: A487.

24 Ohlsson K, Bjork P, Bergenfeldt M, Hageman R, Thompson RC. Interleukin-1 receptor antagonist reduces mortality from endotoxin shock. Nature $1990 ; 348: 550-2$.

25 Bayston KF, Cohen J. Bacterial endotoxin and curren concepts in the diagnosis and treatment of endotoxaemia. f Med Microbiol 1990; 31: 73-83.

26 van Deventer SJ, ten Cate JW, Tytgat GN. Intestinal endotoxemia. Clinical significance. Gastroenterology 1988; 94 : 825-31.

27 Bird NC, Goodman AJ, Johnson AG. Serum phospholipase A2 activity in acute pancreatitis: an early guide to severity. Brf Surg 1989; 76: 731-2.

28 Gross V, Scholmerich J, Leser HG, Salm R, Lausen M Ruckauer $\mathrm{K}$, et al. Granulocyte elastase in assessment of severity of acute pancreatitis. Comparison with acute phase proteins C-reactive protein, alpha l-antitrypsin, and protease inhibitor alpha 2-macroglobulin. Dig Dis Sci 1990; 35: 97-105. 